\title{
Effect of Interferon-Beta Treatment on the Proportion of T Helper 17 Cells and Related Cytokines in Multiple Sclerosis: A Meta-Analysis
}

\author{
Miaomiao Hou, ${ }^{1, *}$ Yufeng Li, ${ }^{2,3,{ }^{*}}$ Lingling He, ${ }^{1, \star}$ Xiaoqiong Li, ${ }^{1}$ Zhibin Ding, ${ }^{1}$ Yaping Du, \\ Yu Zhang, ${ }^{4,5}$ Shengxiao Zhang, ${ }^{6}$ and Xinyi Li ${ }^{1}$
}

T helper 17 (Th17) cells and related cytokines are important in multiple sclerosis (MS), which have become the new therapeutic targets of MS. In published studies, the effect of interferon- $\beta$ (IFN- $\beta$ ) on the proportion of Th17 cells and related cytokines in MS patients remains controversial. We did a meta-analysis to assess the role of IFN$\beta$ on Th17 cells and related cytokines in MS patients. Compared with control subjects, MS patients with IFN- $\beta$ treatment had a lower proportion of Th17 cells in $\mathrm{CD}^{+} \mathrm{T}$ cells of peripheral blood $[-1.49$ ( -2.96 to -0.02$\left.)\right]$, interleukin (IL)-17 level [-1.08 (-1.77 to -0.40$)]$, and IL-23 level [-1.63 (-2.59 to -0.68$)]$ in serum. The results showed that IFN- $\beta$ can reduce the proportion of Th17 cells, the levels of IL-17 and IL-23 in serum of MS.

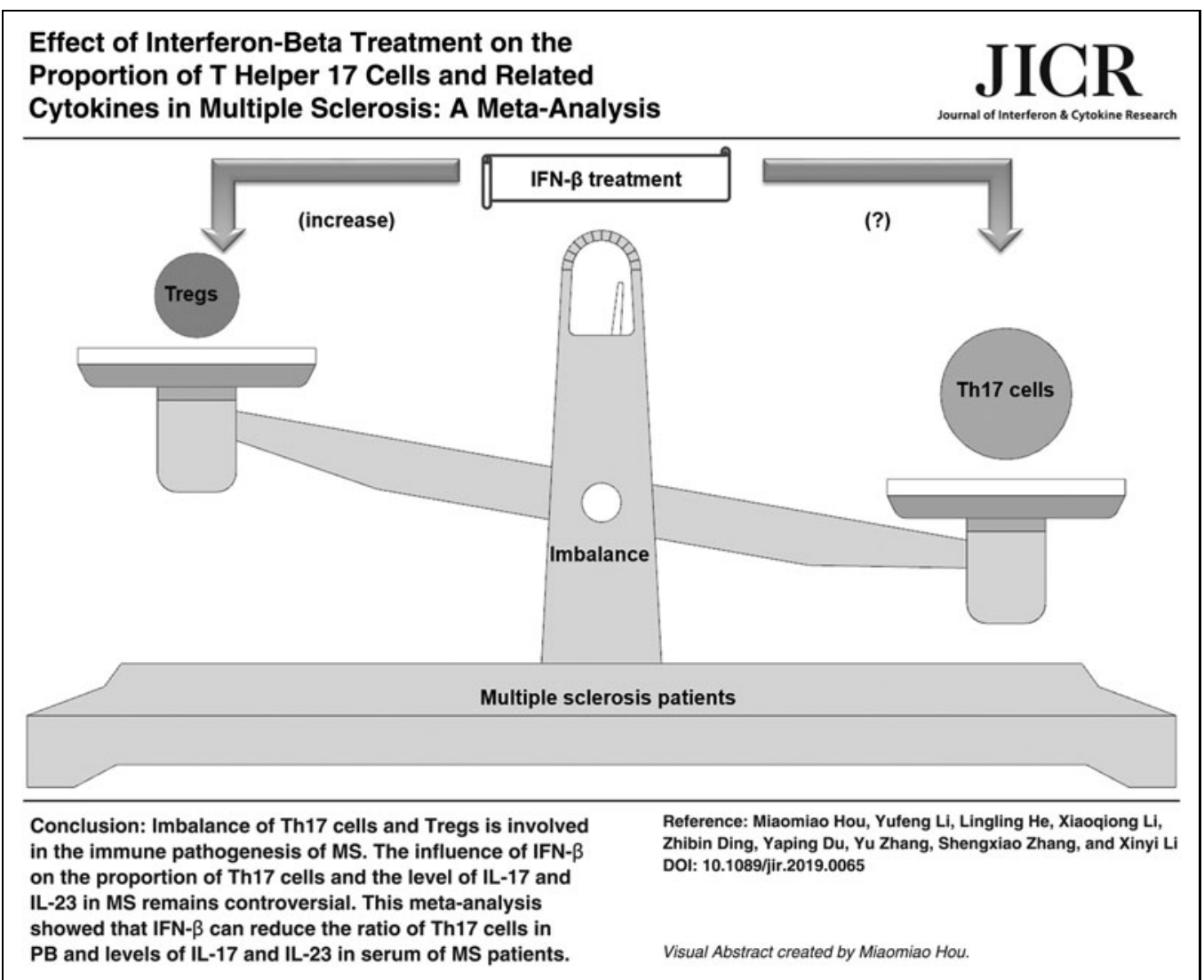

\footnotetext{
${ }^{1}$ Department of Neurology, Shanxi Dayi Hospital Affiliated to Shanxi Medical University, Taiyuan, China.

${ }^{2}$ Department of Neurology and Stroke Center, The First Affiliated Hospital of Jinan University, Jinan University, Guangzhou, China.

${ }^{3}$ Clinical Neuroscience Institute of Jinan University, Jinan University, Guangzhou, China.

${ }^{4}$ Key Laboratory of Cellular Physiology (Shanxi Medical University), Ministry of Education, Taiyuan, China.

${ }^{5}$ Department of Physiology, Shanxi Medical University, Taiyuan, China.

${ }^{6}$ Department of Rheumatology, the Second Hospital of Shanxi Medical University, Taiyuan, China.

*These authors contributed to the work equally and should be regarded as co-first authors.
} 
Keywords: multiple sclerosis, interferon-beta, Th17 cells, interleukin-17, interleukin-23

\section{Introduction}

$\mathrm{M}$ ULTIPLE SCLEROSIS (MS) is an immune-mediated chronic inflammatory demyelinating disease of the central nervous system (CNS) (Noseworthy and others 2000). The balance between Regulatory T cells (Tregs) and T helper 17 (Th17) cells is impaired in MS (Abdolahi and others 2015). Th17 cells and related cytokines take part in the pathogenic mechanism of MS ( $\mathrm{Li}$ and others 2017, 2019). The proportion of Th17 cells and levels of interleukin (IL)-17 and IL-23 are higher in MS (Li and others 2017).

IL-17 is a proinflammatory effector cytokine (Trenova and others 2017). IL-17 induces the expression of chemokines and tumor necrosis factor-alpha, and attracts neutrophilic leukocytes (Kolls and Linden 2004). IL-23 can active the autoreactive and inflammation induction of Th17 cells (Beadling and Slifka 2006; Segal 2010).

Interferon-beta (IFN- $\beta$ ) was approved for treatment of relapsing-remitting MS (Alexander and others 2010). IFN- $\beta$ can reduce the severity of MS, but the immune regulatory and anti-inflammatory mechanisms are unclear (Alexander and others 2010). The influence of IFN- $\beta$ on the proportion of Th17 cells and related cytokines in MS remains controversial (Skrzipek and others 2012).

We reviewed studies about the influence of IFN- $\beta$ on the proportion of Th17 cells and related cytokines in MS systemically, and conducted the meta-analysis to evaluate the impact of IFN- $\beta$ on Th17 cells, IL-17, and IL-23 in MS patients.

\section{Materials and Methods}

\section{Search strategy and selection criteria}

This meta-analysis was based on the Preferred Reporting Items for systematic reviews and meta-analyses (PRISMA) statement (Moher and others 2009). Also, it was registered on the international prospective register of systematic reviews (PROSPERO) (CRD42017065269).
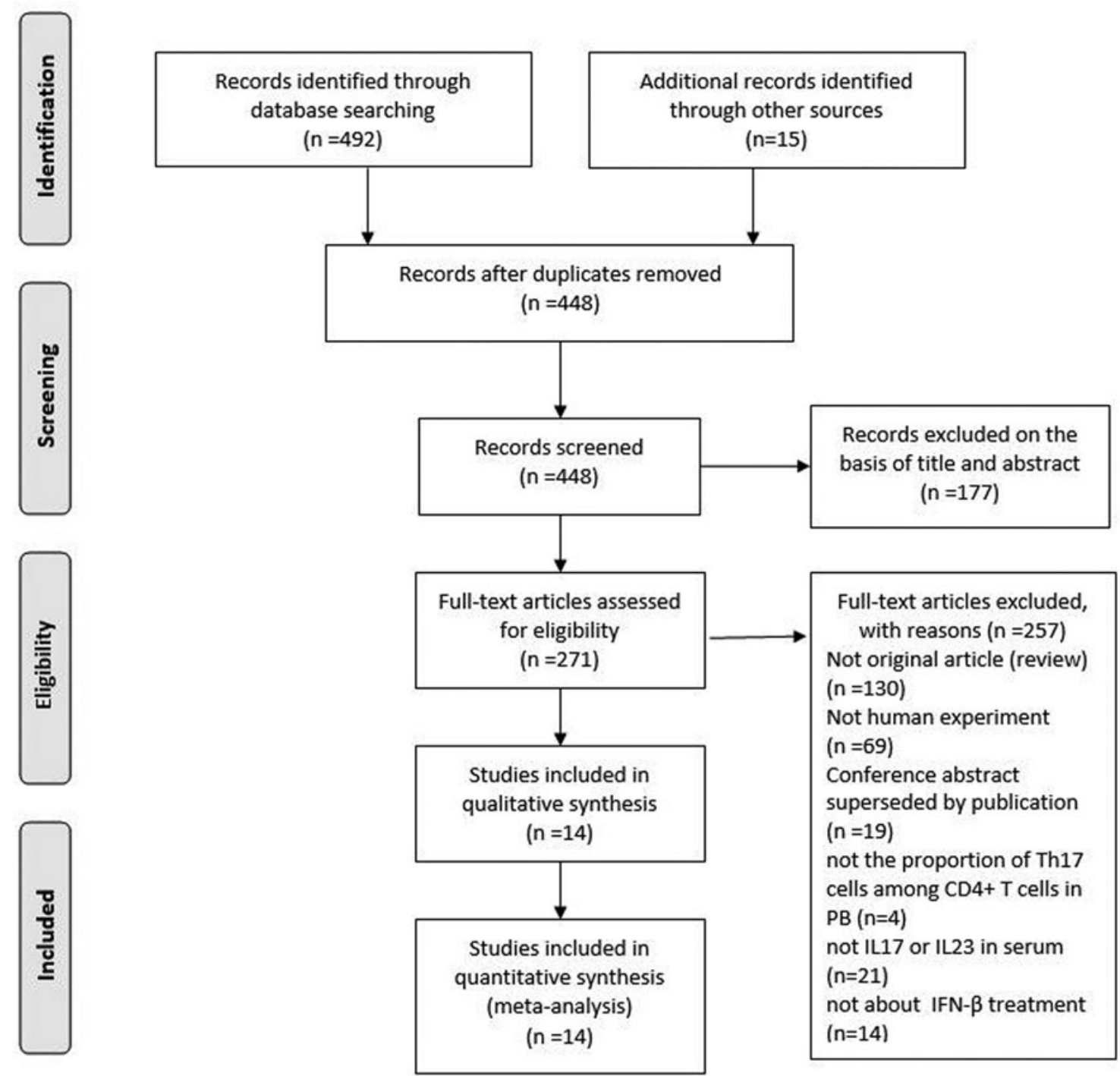

FIG. 1. Study selection process. Th17, T helper 17. 


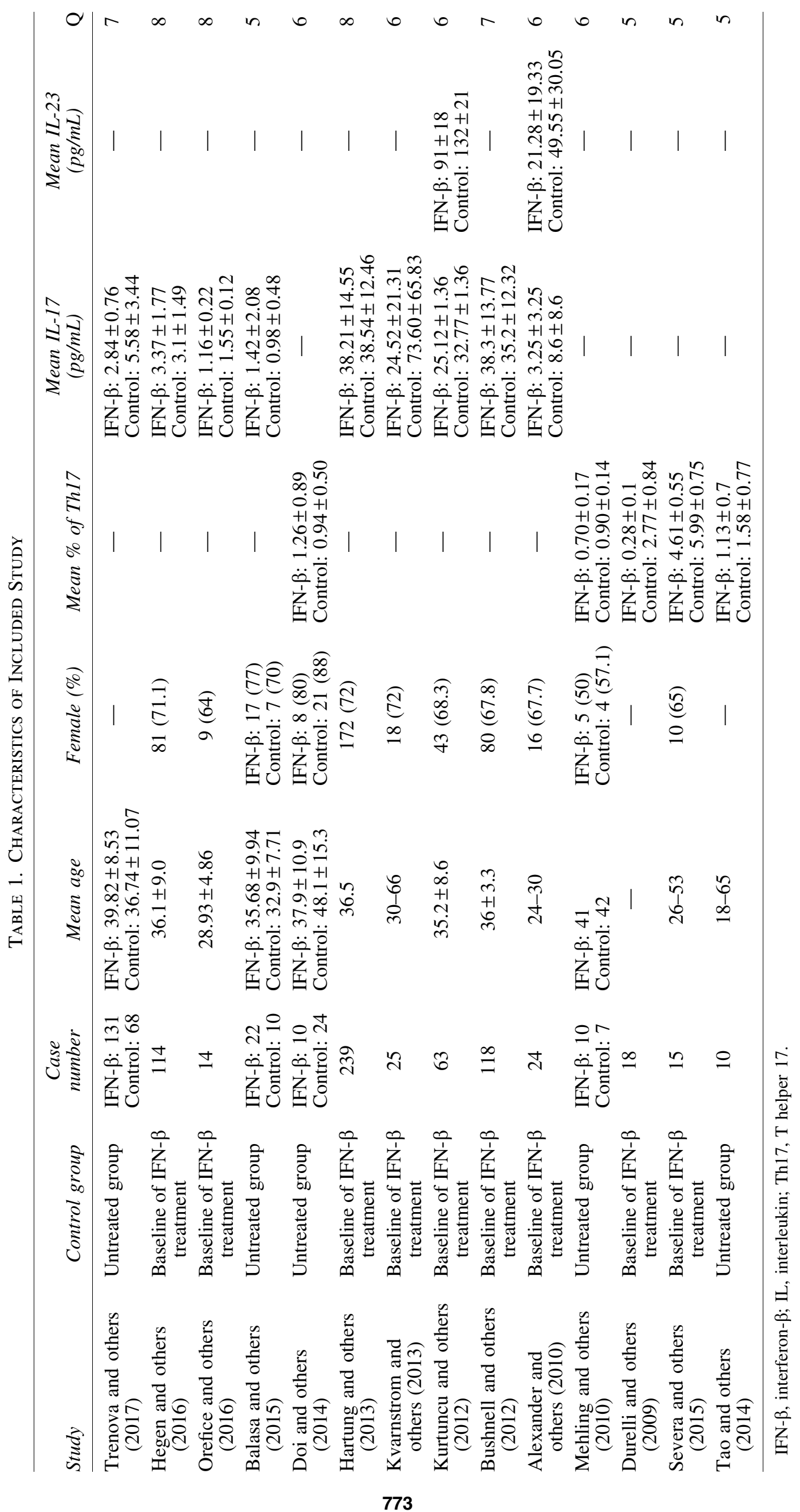




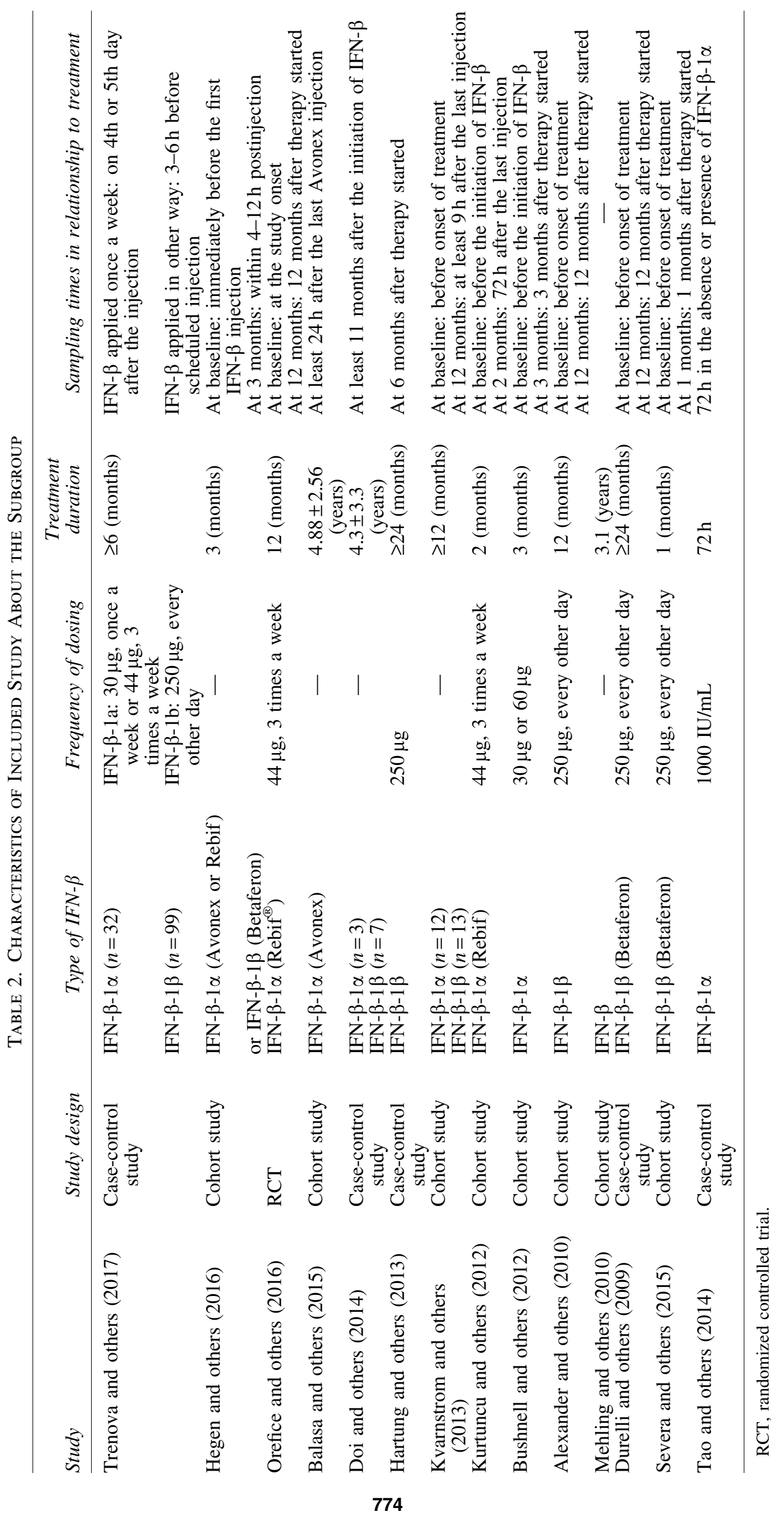


The PubMed, Cochrane, Web of Science, and EMBASE databases were searched by 2 researchers independently. The MeSH terms: "Multiple Sclerosis," "Interferon-beta," "Th17 Cells," "Interleukin-17," "Interleukin-23" and related free words were used to search relevant articles. All studies were published before April 30, 2019.

\section{Study selection}

Inclusion criteria were the following: (1) original studies; (2) researches about human; (3) full text published in English; (4) "Multiple Sclerosis" and "Interferon-beta" and "“Th17 Cells' or 'Interleukin-17' or 'Interleukin-23"," are included in title or abstract; and (5) studies about the proportion of Th17 cells in CD4 ${ }^{+} \mathrm{T}$ cells or levels of IL-17 and IL-23 in serum in MS with IFN- $\beta$ treatment.

Exclusion criteria were the following: (1) nonoriginal studies; (2) studies with no suitable comparison group; (3) the data are incomplete and cannot be obtained by contacting authors of the original studies; (4) multiple publications or overlapping subjects; (5) studies with the proportion of Th17 cells in $\mathrm{CD}^{+} \mathrm{T}$ cells or other cells, while not $\mathrm{CD}^{+} \mathrm{T}$ cells; (6) studies about the levels of IL-17 and IL-23 in plasma or intracellular; and (7) all sampling before the IFN- $\beta$ treatment, while not after the IFN- $\beta$ treatment.

\section{Data extraction and quality assessment}

Two independent researchers (M.H., Y.L.) reviewed the studies and extracted data. Disagreements would be discussed with the third investigator (L.H.). The following data were extracted from all selected studies: author, published year, case number, mean age, female $(\%)$, and ratio of Th17 cells in $\mathrm{CD}^{+} \mathrm{T}$ cells, IL-17 serum levels, and IL-23 serum levels, study design, IFN- $\beta$ therapy, including the type of IFN, frequency of dosing, treatment duration, and sampling times in relationship to treatment. The Newcastle-Ottawa Quality Assessment Scale (Stang 2010) was adopted to evaluate the quality $(Q)$ of each study.

\section{Statistical analysis}

There were 3 outcomes which were all continuous variables: the proportion of Th17 cells in peripheral blood (PB) and the levels of IL-17 and IL-23 in serum. Standardized mean differences and $95 \%$ confidence interval were used to assess the proportion of Th17 cells, the levels of IL-17 and IL-23 in MS with IFN- $\beta$ treatment and controls.

We assessed publication bias using Begg and Egger tests, $P<0.05$ was considered as a publication bias. The influence of publication bias on the results was determined by trimand-fill method. The Q test and $I^{2}$ test were adopted to value the heterogeneity, $P \geq 0.1$ or $I^{2} \leq 50 \%$ was considered as no significant heterogeneity, the fixed-effects model was applied, conversely, the random-effects model (REM) would be applied. Sensitivity analysis was used to value the robustness. Stata (version 14.0) was used for all statistical analyses and generated images.

\section{Results}

\section{Study characteristics}

Through searching, we finally identified 507 studies. According to the inclusion and exclusion criteria, 14 studies

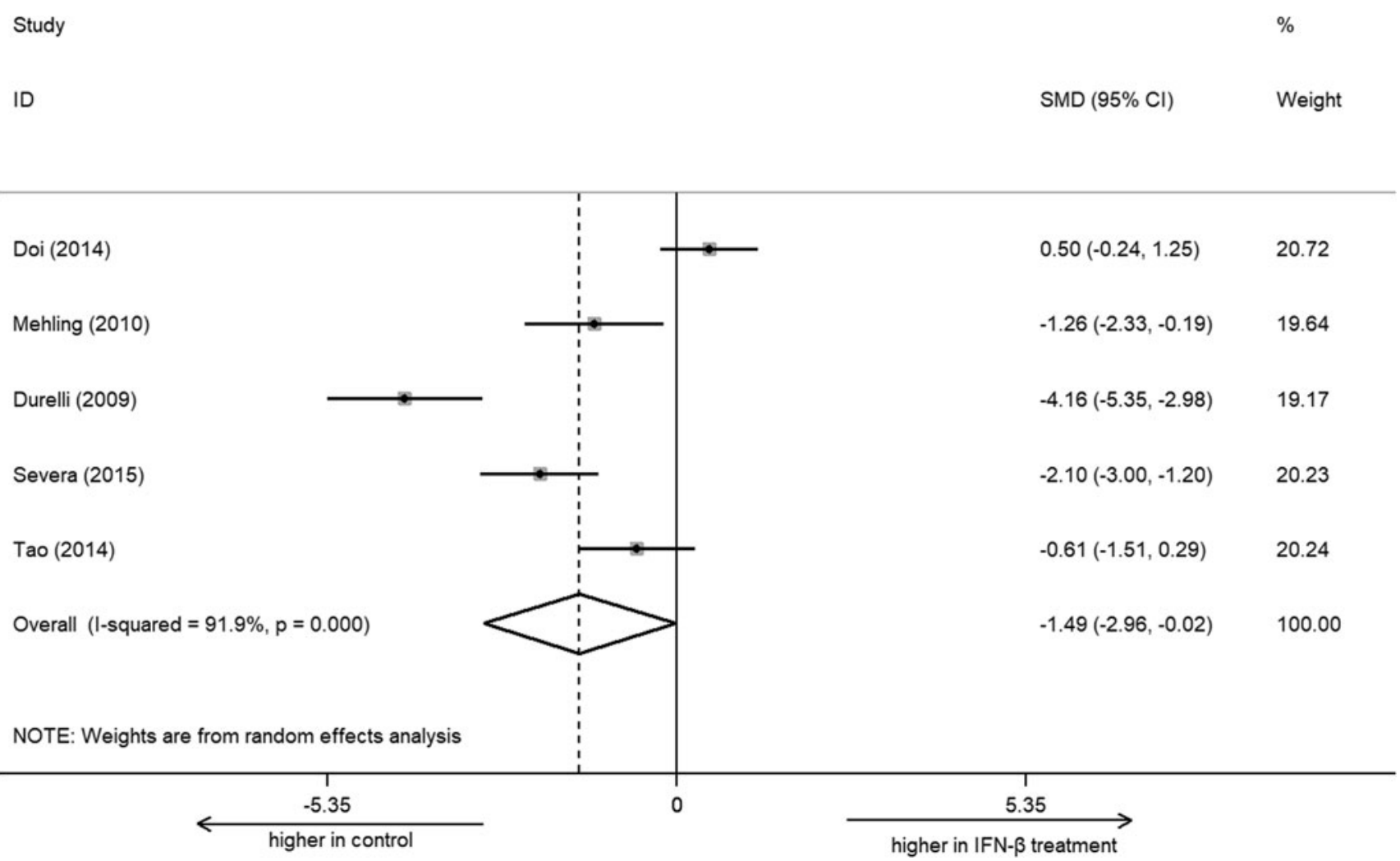

FIG. 2. Forest plot for combined meta-analysis of in the proportion of Th17 cells among CD4+ T cells in PB. PB, peripheral blood. 
were included in the meta-analysis (Fig. 1). The screening process was shown in Fig. 1, and the details of the included studies were shown in Tables 1 and 2. All 14 studies were published between 2009 and 2017.

\section{The proportion of Th17 cells of MS with IFN- $\beta$ treatment}

There were five included studies analyzed the proportion of Th17 cells. The results showed that there was significant difference in the ratio of Th17 cells between MS with IFN$\beta$ treatment and control subjects $[-1.49$ ( -2.96 to -0.02$)$, $P=0.048]$ (Fig. 2). The heterogeneity among studies was high $\left(I^{2} 91.90 \%\right)$. The high heterogeneity among studies was found, and the REM of meta-analysis was used in the forest plots.

Considering the possible sources of heterogeneity, we conducted a subgroup analysis of the proportion of Th17 cells in CD4+ T cells about the types of the control group, the study design, and the types of IFN- $\beta$, frequency of dosing, treatment duration, and sampling times in relationship to treatment (Table 3).

\section{The IL-17 level in MS with IFN- $\beta$ treatment}

There were 9 included studies that analyzed the $I L-17$ level. Results showed that significant difference was found between MS patients with IFN- $\beta$ treatment and controls in the serum level of IL-17[ $-1.08(-1.77$ to -0.40$), P=0.002]$ (Fig. 3). The heterogeneity among studies was high $\left(I^{2}\right.$ 97.30\%). Considering the possible sources of heterogeneity, we conducted a subgroup analysis of the IL-17 level in serum about the type of the control group, the study design, the type of IFN- $\beta$, frequency of dosing, treatment duration, and sampling times in relationship to treatment (Table 3).

Table 3. Summary of the Meta-Analysis Results

\begin{tabular}{|c|c|c|c|c|c|}
\hline \multirow[b]{2}{*}{ Analysis } & \multirow[b]{2}{*}{$\mathrm{N}$} & \multicolumn{2}{|c|}{ Random-effects model } & \multicolumn{2}{|c|}{ Heterogeneity } \\
\hline & & $S M D(95 \% C I)$ & $\mathrm{P}$ & $\mathrm{I}^{2}(\%)$ & $\mathrm{P}$ \\
\hline $\begin{array}{l}\text { The proportion of Th17 cells in } \mathrm{CD}^{+} \mathrm{T} \text { cells } \\
\text { Subgroup 1: control group }\end{array}$ & 5 & $-1.489(-2.963$ to -0.016$)$ & 0.048 & 91.90 & 0 \\
\hline $\begin{array}{l}\text { Untreated group } \\
\text { Baseline of IFN- } \beta \text { treatment }\end{array}$ & $\begin{array}{l}2 \\
3\end{array}$ & $\begin{array}{l}-0.335(-2.063 \text { to } 1.392) \\
-2.257(-4.145 \text { to }-0.368)\end{array}$ & $\begin{array}{l}0.704 \\
0.019\end{array}$ & $\begin{array}{l}85.80 \\
90.90\end{array}$ & $\begin{array}{l}0.008 \\
0\end{array}$ \\
\hline $\begin{array}{l}\text { Subgroup } 2 \text { : type of IFN- } \beta \\
\text { IFN- } \beta-1 \alpha \text { or IFN- } \beta-1 \beta \\
\text { IFN- }-1 \beta \\
\text { IFN- } \beta-1 \alpha\end{array}$ & $\begin{array}{l}2 \\
2 \\
1\end{array}$ & $\begin{array}{l}-0.335(-2.063 \text { to } 1.392) \\
-3.093(-5.115 \text { to }-1.072) \\
-0.612(-1.511 \text { to } 0.287)\end{array}$ & $\begin{array}{l}0.704 \\
0.003 \\
0.182\end{array}$ & $\begin{array}{r}85.80 \\
86.40 \\
-\end{array}$ & $\begin{array}{l}0.008 \\
0.007 \\
-\end{array}$ \\
\hline $\begin{array}{l}\text { Subgroup 3: frequency of dosing } \\
\text { Others } \\
250 \mu \mathrm{g} \text {, every other day } 1\end{array}$ & $\begin{array}{l}3 \\
2\end{array}$ & $\begin{array}{l}-0.404(-1.439 \text { to } 0.631) \\
-3.093(-5.115 \text { to }-1.072)\end{array}$ & $\begin{array}{l}0.444 \\
0.003\end{array}$ & $\begin{array}{l}74.90 \\
86.40\end{array}$ & $\begin{array}{l}0.018 \\
0.007\end{array}$ \\
\hline $\begin{array}{l}\text { Subgroup 4: treatment duration and sampling } \\
\geq 3 \text { months } \\
<3 \text { months }\end{array}$ & $\begin{array}{c}\text { nes } \\
3 \\
2\end{array}$ & $\begin{array}{l}\text { relationship to treatment } \\
-1.609(-4.256 \text { to } 1.037) \\
-1.354(-2.812 \text { to } 0.103)\end{array}$ & $\begin{array}{l}0.233 \\
0.068\end{array}$ & $\begin{array}{l}95.40 \\
80.90\end{array}$ & $\begin{array}{l}0 \\
0.022\end{array}$ \\
\hline $\begin{array}{l}\text { Subgroup 5: study design } \\
\text { Case-control study } \\
\text { Cohort study }\end{array}$ & $\begin{array}{l}3 \\
2\end{array}$ & $\begin{array}{l}-1.806(-6.379 \text { to } 2.768) \\
-1.325(-2.217 \text { to }-0.434)\end{array}$ & $\begin{array}{l}0.439 \\
0.004\end{array}$ & $\begin{array}{l}97.70 \\
61.90\end{array}$ & $\begin{array}{l}0 \\
0.072\end{array}$ \\
\hline $\begin{array}{l}\text { The IL-17 level in serum } \\
\text { Subgroup 1: control group } \\
\text { Untreated group } \\
\text { Baseline of IFN- } \beta \text { treatment }\end{array}$ & $\begin{array}{l}2 \\
7\end{array}$ & $\begin{array}{l}-1.082(-1.766 \text { to }-0.397) \\
-0.566(-2.089 \text { to } 0.956) \\
-1.229(-2.012 \text { to }-0.446)\end{array}$ & $\begin{array}{l}0.002 \\
0.466 \\
0.002\end{array}$ & $\begin{array}{l}97.30 \\
92.80 \\
97.50\end{array}$ & $\begin{array}{l}0 \\
0 \\
0\end{array}$ \\
\hline $\begin{array}{l}\text { Subgroup } 2 \text { : type of IFN- } \beta \\
\text { IFN- } \beta-1 \alpha \text { or IFN- } \beta-1 \beta \\
\text { IFN- } \beta-1 \beta \\
\text { IFN- } \beta-1 \alpha\end{array}$ & $\begin{array}{l}2 \\
2 \\
5\end{array}$ & $\begin{array}{l}-1.237(-1.518 \text { to }-0.955) \\
-0.372(-1.148 \text { to } 0.404) \\
-1.386(-2.715 \text { to }-0.056)\end{array}$ & $\begin{array}{l}0 \\
0.347 \\
0.041\end{array}$ & $\begin{array}{l}0 \\
84.50 \\
98.20\end{array}$ & $\begin{array}{l}0.377 \\
0.011 \\
0\end{array}$ \\
\hline $\begin{array}{l}\text { Subgroup 3: frequency of dosing } \\
\text { Others } \\
44 \mu \mathrm{g}, 3 \text { times a week } \\
250 \mu \mathrm{g} \text {, every other day } 1\end{array}$ & $\begin{array}{l}6 \\
2 \\
1\end{array}$ & $\begin{array}{l}-0.274(-0.744 \text { to } 0.196) \\
-3.924(-7.280 \text { to }-0.569) \\
-0.823(-1.413 \text { to }-0.233)\end{array}$ & $\begin{array}{l}0.253 \\
0.022 \\
0.006\end{array}$ & $\begin{array}{r}93.90 \\
96.60 \\
-\end{array}$ & $\begin{array}{l}0 \\
0 \\
0\end{array}$ \\
\hline $\begin{array}{l}\text { Subgroup 4: treatment duration and sampling } \\
\geq 3 \text { months } \\
<3 \text { months }\end{array}$ & $\begin{array}{c}\text { nes } \\
8 \\
1\end{array}$ & $\begin{array}{l}\text { relationship to treatment } \\
-0.513(-0.968 \text { to }-0.058) \\
-5.625(-6.407 \text { to }-4.843)\end{array}$ & $\begin{array}{l}0.027 \\
0\end{array}$ & $\stackrel{93.40 \%}{-}$ & ${ }^{0}$ \\
\hline $\begin{array}{l}\text { Subgroup 5: study design } \\
\text { Case-control study } \\
\text { Cohort study } \\
\text { Randomized controlled trial }\end{array}$ & $\begin{array}{l}2 \\
6 \\
1\end{array}$ & $\begin{array}{l}-0.658(-1.913 \text { to } 0.598) \\
-1.093(-2.173 \text { to }-0.014) \\
-2.201(-3.153 \text { to }-1.249)\end{array}$ & $\begin{array}{l}0.304 \\
0.047 \\
0\end{array}$ & $\begin{array}{c}97.90 \% \\
97.80 \% \\
-\end{array}$ & $\begin{array}{l}0 \\
0 \\
-\end{array}$ \\
\hline
\end{tabular}

CI, confidence interval; SMD, standardized mean differences. 


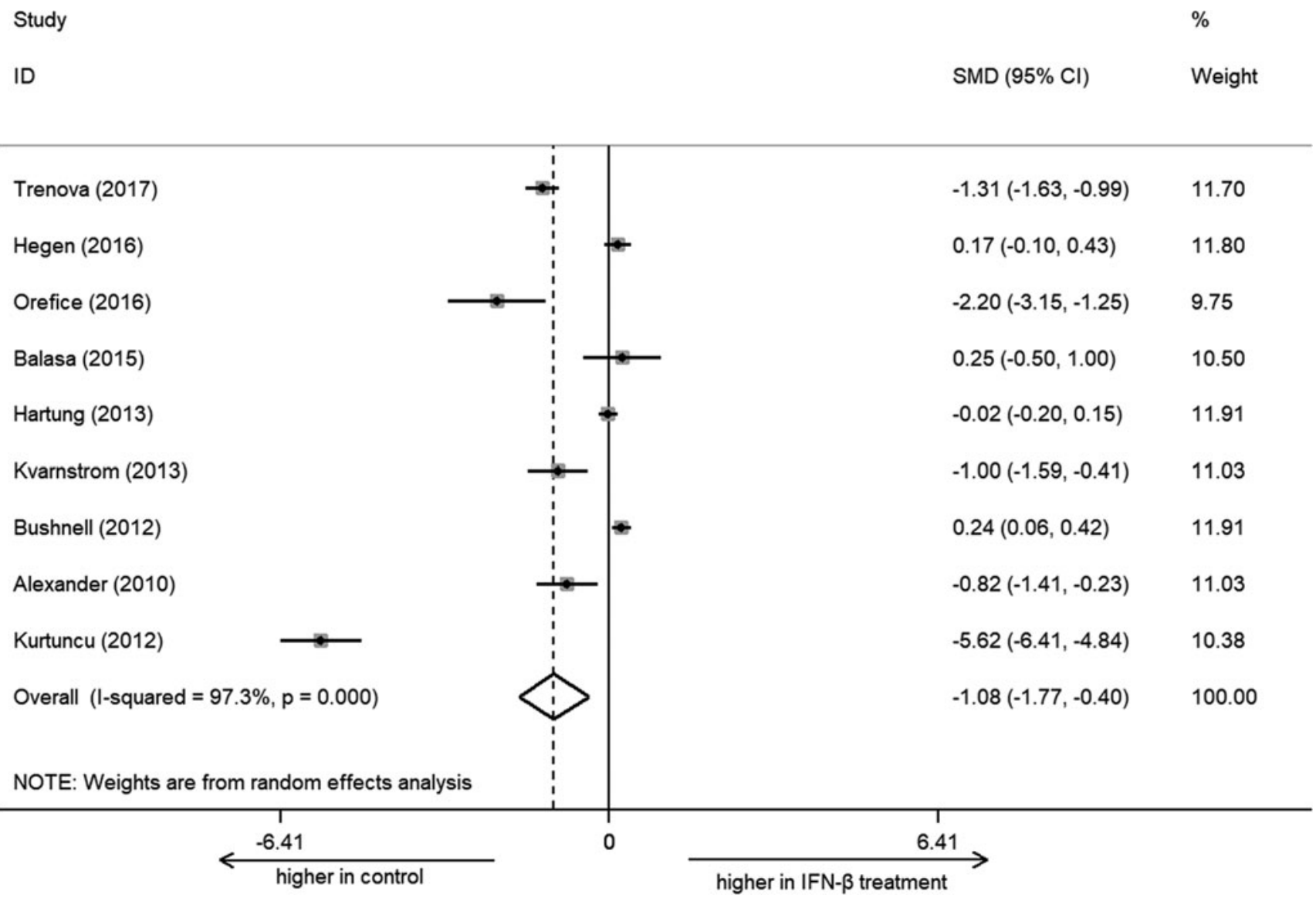

FIG. 3. Forest plot for combined meta-analysis of the serum levels of IL-17. IL, interleukin.

We showed the sensitivity analysis of the articles about serum levels of IL-17 (Supplementary Fig. S1). Publication bias was detected by Egger test $(P=0.046)$, while not by beg test $(P=0.118)$, and trim-and-fill test revealed that publication bias of studies did not impact the estimates (Table 4).

\section{The IL-23 level in MS with IFN- $\beta$ treatment}

There were 2 included studies that analyzed the $I L-23$ level. There was significant difference between MS patients with IFN- $\beta$ treatment and controls in the serum levels of IL-23 [ -1.63 ( -2.59 to -0.68$), P=0.001]$ (Fig. 4$)$, and the heterogeneity among studies was high $\left(I^{2} 84.7 \%\right)$. Con-

Table 4. The Trim-And-Fill TeSt About IL-17 LEVEL in SERUM

\begin{tabular}{|c|c|c|c|c|c|c|}
\hline \multirow[b]{2}{*}{ Method } & \multirow{2}{*}{$\begin{array}{c}\text { Pooled } \\
\text { Test }\end{array}$} & \multicolumn{2}{|c|}{$95 \% C I$} & \multicolumn{2}{|c|}{ Asymptotic } & \multirow{2}{*}{$\begin{array}{l}\text { No. of } \\
\text { studies }\end{array}$} \\
\hline & & Lower & Upper & $\mathrm{Z}$ & $\mathrm{P}$ & \\
\hline \multicolumn{7}{|c|}{ Meta-analysis } \\
\hline Fixed & -0.211 & -0.312 & -0.109 & -4.05 & 0 & 9 \\
\hline Random & -1.082 & -1.766 & -0.397 & -3.095 & 0.002 & 9 \\
\hline \multicolumn{7}{|c|}{ Filled meta-analysis } \\
\hline Fixed & -0.962 & -1.051 & -0.874 & -21.376 & 0 & 11 \\
\hline Random & -1.504 & -2.509 & -0.500 & -2.936 & 0.003 & 11 \\
\hline
\end{tabular}

sidering that there were just 2 studies, we did not conduct a subgroup analysis.

\section{Discussion}

MS is a chronic and organ-specific autoimmune disease, resulting in CNS damage (Dolati and others 2018). MS is an important cause of disability in young people. Therefore, it is of great value and significance to study the mechanism of MS and related drug treatment. Imbalance of Th17 cells and Tregs is involved in the immune pathogenesis of MS (Abdolahi and others 2015). Restoring this balance has important guiding significance for the research of drug mechanism of MS. In another article (under review), we have shown that INF- $\beta$ can increase the level of Tregs in MS. However, the influence of IFN- $\beta$ on the proportion of Th17 cells and the level of IL-17 and IL-23 in MS remains controversial. So, we did this meta-analysis to assess the exact role of IFN- $\beta$ on Th17 cells, IL-17, and IL-23 in MS patients.

Our results revealed that, there were significant differences between MS patients with IFN- $\beta$ treatment and controls of the percentage of Th17 cells and levels of IL-17 and IL-23. Combining the results of another article "Effect of interferon-beta treatment on the proportion of regulatory T cells in multiple sclerosis: a meta-analysis" (under review), we came to the conclusion that IFN- $\beta$ can regulate the balance of Tregs/Th17 cells by increasing the level of Tregs, decreasing the proportion of Th17 cells and the 


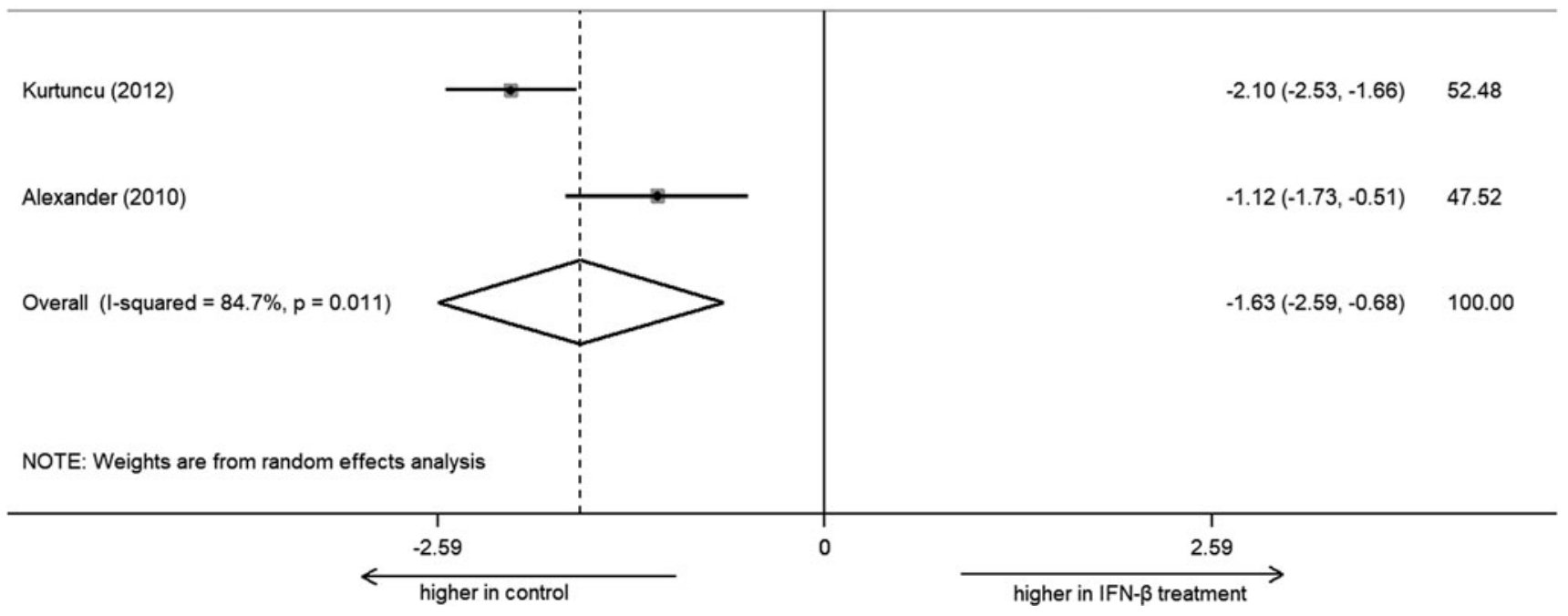

FIG. 4. Forest plot for combined meta-analysis of the serum levels of IL-23.

levels of IL-17 and IL-23, and then exert immunomodulatory effects on MS.

This study has several obvious limitations and deficiencies. First, the heterogeneity was high, although we conducted a subgroup analysis about the type of the control group, the study design, and aspects of IFN-beta therapy, $I^{2}$ was still above $50 \%$. The number of articles was not too much, and we could not thoroughly analyze the source of the heterogeneity of the results. Secondly, disease severity and duration and the detection methods were inconsistent in the included studies, which may affect the therapeutic effect of IFN- $\beta$ and the ratio of Th17 cells and the levels of IL-17 and IL-23. Third, the articles were not enough to make the funnel graph. Egger test showed that there was publication bias in the study, but the trim-and-fill test showed that the publication bias of IL-17 did not impact the estimates. Finally, we only analyzed the ratio of Th17 cells, levels of IL-17, and IL-23. Th17 cells coproduce IL-21, IL-22, and other cytokines. Except for IL-23, all cytokines, including IL-21, IL-1b, and IL-6, are conductive to the differentiation of Th17 cells. In the future, we will continue to pay attention to the latest research in this field.

In conclusion, our findings show that IFN- $\beta$ can reduce the ratio of Th17 cells in PB and levels of IL-17 and IL-23 in serum of MS patients. Further large sample size scientific studies are needed to study the immune mechanism of IFN$\beta$ on MS.

\section{Author Disclosure Statement}

No competing financial interests exist.

\section{Funding Information}

This work got support from the Shanxi Graduate Education Innovation Project (No. 2018BY070) and the interna- tional scientific and technological cooperation project (No. 201703D421018).

\section{Supplementary Material}

Supplementary Figure S1

\section{References}

Abdolahi M, Yavari P, Honarvar NM, Bitarafan S, Mahmoudi M, Saboor-Yaraghi AA. 2015. Molecular mechanisms of the action of vitamin A in Th17/Treg axis in multiple sclerosis. J Mol Neurosci 57(4):605-613.

Alexander JS, Harris MK, Wells SR, Mills G, Chalamidas K, Ganta VC, McGee J, Jennings MH, Gonzalez-Toledo E, Minagar A. 2010. Alterations in serum MMP-8, MMP-9, IL12 p40 and IL-23 in multiple sclerosis patients treated with interferon-beta1b. Mult Scler 16(7):801-809.

Balasa R, Maier S, Voidazan S, Hutanu A, Bajko Z, Motataianu A. 2015. An intricate mechanism of action of avonex in relapsing remitting multiple sclerosis patients: variation of serum titre of interleukin-17A, interleukin-10 and transforming growth factor-beta. CNS Neurol Disord Drug Targets 14(6): 804-810.

Beadling C, Slifka MK. 2006. Regulation of innate and adaptive immune responses by the related cytokines IL-12, IL-23, and IL-27. Arch Immunol Ther Exp (Warsz) 54(1):15-24.

Bushnell SE, Zhao Z, Stebbins CC, Cadavid D, Buko AM, Whalley ET, Davis JA, Versage EM, Richert JR, Axtell RC, Steinman L, Medori R. 2012. Serum IL-17F does not predict poor response to IM IFNbeta-1a in relapsing-remitting MS. Neurology 79(6):531-537.

Doi H, Song ZY, Yoshimura S, Tateishi T, Yonekawa T, Yamasaki R, Murai H, Matsushita T, Kira JI. 2014. Distinct cytokine and $\mathrm{T}$ helper cell profiles between patients with multiple sclerosis who had or had not received interferonbeta. Clin Exp Neuroimmunol 5(3):321-327. 
Dolati S, Marofi F, Babaloo Z, Aghebati-Maleki L, Roshangar L, Ahmadi M, Rikhtegar R, Yousefi M. 2018. Dysregulated network of miRNAs involved in the pathogenesis of multiple sclerosis. Biomed Pharmacother 104:280-290.

Durelli L, Conti L, Clerico M, Boselli D, Contessa G, Ripellino P, Ferrero B, Eid P, Novelli F. 2009. T-helper 17 cells expand in multiple sclerosis and are inhibited by interferon-beta. Ann Neurol 65(5):499-509.

Hartung HP, Steinman L, Goodin DS, Comi G, Cook S, Filippi M, O'Connor P, Jeffery DR, Kappos L, Axtell R, Knappertz V, Bogumil T, Schwenke S, Croze E, Sandbrink R, Pohl C. 2013. Interleukin $17 \mathrm{~F}$ level and interferon beta response in patients with multiple sclerosis. JAMA Neurol 70(8):1017-1021.

Hegen H, Adrianto I, Lessard CJ, Millonig A, Bertolotto A, Comabella M, Giovannoni G, Guger M, Hoelzl M, Khalil M, Fazekas F, Killestein J, Lindberg RL, Malucchi S, Mehling M, Montalban X, Rudzki D, Schautzer F, Sellebjerg F, Sorensen PS, Deisenhammer F, Steinman L, Axtell RC. 2016. Cytokine profiles show heterogeneity of interferon-beta response in multiple sclerosis patients. Neurol Neuroimmunol Neuroinflamm 3(2):e202.

Kolls JK, Linden A. 2004. Interleukin-17 family members and inflammation. Immunity 21(4):467-476.

Kurtuncu M, Tuzun E, Turkoglu R, Petek-Balci B, Icoz S, Pehlivan M, Birisik O, Ulusoy C, Shugaiv E, Akman-Demir G, Eraksoy M. 2012. Effect of short-term interferon-beta treatment on cytokines in multiple sclerosis: significant modulation of IL-17 and IL-23. Cytokine 59(2):400-402.

Kvarnstrom M, Ydrefors J, Ekerfelt C, Vrethem M, Ernerudh J. 2013. Longitudinal interferon-beta effects in multiple sclerosis: differential regulation of IL-10 and IL-17A, while no sustained effects on IFN-gamma, IL-4 or IL-13. J Neurol Sci 325(1-2):79-85.

Li YF, Zhang SX, Ma XW, Xue YL, Gao C, Li XY. 2017. Levels of peripheral Th17 cells and serum Th17-related cytokines in patients with multiple sclerosis: a meta-analysis. Mult Scler Relat Disord 18:20-25.

Li YF, Zhang SX, Ma XW, Xue YL, Gao C, Li XY, Xu AD. 2019. The proportion of peripheral regulatory $\mathrm{T}$ cells in patients with Multiple Sclerosis: a meta-analysis. Mult Scler Relat Disord 28:75-80.

Mehling M, Lindberg R, Raulf F, Kuhle J, Hess C, Kappos L, Brinkmann V. 2010. Th17 central memory T cells are reduced by FTY720 in patients with multiple sclerosis. Neurology 75(5):403-410.

Moher D, Liberati A, Tetzlaff J, Altman DG. 2009. Reprintpreferred reporting items for systematic reviews and metaanalyses: the PRISMA statement. Phys Ther 89(9):873-880.
Noseworthy JH, Lucchinetti C, Rodriguez M, Weinshenker BG. 2000. Multiple sclerosis. N Engl J Med 343(13):938952.

Orefice NS, Alhouayek M, Carotenuto A, Montella S, Barbato F, Comelli A, Calignano A, Muccioli GG, Orefice G. 2016. Oral palmitoylethanolamide treatment is associated with reduced cutaneous adverse effects of interferon-betala and circulating proinflammatory cytokines in relapsingremitting multiple sclerosis. Neurotherapeutics 13(2):428438.

Segal BM. 2010. Th17 cells in autoimmune demyelinating disease. Semin Immunopathol 32(1):71-77.

Severa M, Rizzo F, Giacomini E, Annibali V, Gafa V, Romano S, Buscarinu MC, Fornasiero A, Salvetti M, Coccia EM. 2015. IFN-beta therapy regulates TLR7-mediated response in plasmacytoid dendritic cells of multiple sclerosis patients influencing an anti-inflammatory status. J Interferon Cytokine Res 35(9):668-681.

Skrzipek S, Vogelgesang A, Broker BM, Dressel A. 2012. Differential effects of interferon-betalb on cytokine patterns of CD4+ and CD8+ T cells derived from RRMS and PPMS patients. Mult Scler 18(5):674-678.

Stang A. 2010. Critical evaluation of the Newcastle-Ottawa scale for the assessment of the quality of nonrandomized studies in meta-analyses. Eur J Epidemiol 25(9):603-605.

Tao Y, Zhang X, Chopra M, Kim MJ, Buch KR, Kong D, Jin J, Tang Y, Zhu H, Jewells V, Markovic-Plese S. 2014. The role of endogenous IFN-beta in the regulation of Th17 responses in patients with relapsing-remitting multiple sclerosis. J Immunol 192(12):5610-5617.

Trenova AG, Slavov GS, Manova MG, Draganaova-Filipova MN, Mateva NG, Miteva LD, Stanilova SA. 2017. Alterations in serum levels of IL-17 in contrast to TNF-alpha correspond to disease-modifying treatment in relapsing-remitting multiple sclerosis. Scand J Clin Lab Invest 77(4):283-288.

Address correspondence to: Dr. Xinyi $\mathrm{Li}$

Department of Neurology Shanxi Dayi Hospital Affiliated to Shanxi Medical University 99 Longcheng Street Taiyuan 030024

China

E-mail: xinyili2003@163.com

Received 20 March 2019/Accepted 4 June 2019 